\title{
SOCIO-ECONOMIC-GENDER DISBALANCES IN GEORGIA
}

\section{NINO ABESADZE}

\section{Associate Professor}

Ivane Javakhishvili Tbilisi State University, Georgia

nino.abesadze@tsu.ge

\section{NATALIA ROBITASHVILI}

\section{Assistant Professor}

Batumi Shota Rustaveli State University, Georgia

robnato@mail.ru

\section{OTAR ABESADZE}

\section{Assistant Professor}

Caucasus University, Georgia

o.abesadze@gmail.com

\section{KEYWORDS: EMPLOYMENT, GENDER, STEREOTYPE, INDEXES, RATE}

For citation: Abesadze N., Robitashvili N., Abesadze O. (2019), Socio-Economic-Gender Disbalances In Georgia, Globalization And Business, №7, pp. 143-147. https://doi.org/10.35945/gb.2019.07.017

\section{INTRODUCTION}

The considered issue is very urgent for the Georgian reality in both, theoretical and practical respects, as the analysis and forecast of the employment dynamics in gender respect is necessary for the development and realization of the proper gender policy. The present reality of Georgia makes it necessary to significantly improve the information and methodological background of the abovedescribed problems. The work gives the modified employment indices in gender respect and major results of the economic analysis of the problem. In addition, it includes comparative analysis of unemployment in Georgia in gender respect, and the estimated figures of unemployment are gained by using modern mathematical and computing methods. (Abesadze, 2013)

A policy of gender equality made Georgia one of the most reformative countries in Caucasus. However, in spite of many positive steps, there are certain problems related to a low level of civil consciousness and strong societal stereotypes. Caucasian mentality and patriarchal environment also aggravate the problems. Probably this is one of the reasons, why according to gender index, Georgia lags behind countries, such as Tanzania, Ghana, Vietnam, Uzbekistan, Nicaragua and others. According to this classification in 2016,
Georgia occupies 90th position from 144 countries. The top three countries of global gender index are Iceland, Norway and Finland. Indicators of Montenegro, Uruguay, Greece and Indonesia are close to us, but we are ahead of Japan, Armenia, Hungary, Slovakia and others.

According to the above-mentioned report, number of women has increased at the global market since 2006 and comprises 250 million. However, inequality of wages still remains a problem. According to GIA, a gender disbalance is corrected by $4 \%$ in the fields, such as health protection, education, economy and policy. (Global-gender-gap-report-2016) We may say that political efforts to correct the gender disbalance are taking place, but in other fields, such as employment, we have many problems and some of them are quite deep.

Georgian Parliament has enacted a law against a domestic violence in 2006 and a law about a gender equality in 2010 to guarantee women's security, equality at the labor market and women's political integration. Election code has been changed in 2012 to support political parties, if they tried to protect the gender balance. However, this regulation didn't bring significant improvement. After parliamentary elections of 2012 , women occupied only $11 \%$ of parliamentary mandates, but this number was higher than in the previous parliament. 
At the local level, representation of women is even weaker. In 2016, number of women has increased compared to 2012, but level of representation of women is still low in Georgian parliament. From 150 deputies of Georgian parliament of 2017, women are only 22 and it is only $14.7 \%$. We have the same picture at the executive level. From 11 ministers only 3 are women. In parliaments of certain countries $30-40 \%$ are women. (Georgian law about gender equality, 2010). In private sector percent of employed women is higher, but majority of them occupies low-wage positions, whereas majority of men has executive positions or their wages are higher. Society still has an opinion, that it is better for women to play less active and less prestigious professional roles to combine societal activities and family business (and spend more time in caring family and children).

\section{METHODOLOGY/METHODS}

Efficient employment statistical analysis in gender respect is possible only by using relevant statistical methods. The work, through the combined application of methods of statistical observation, grouping and analysis, studies the employment dynamics in gender respect based on the method of fixed numbers. This has enabled us to identify the nature of employment changes in gender respect and impact of the factors on the changes of this phenomenon functionally linked to the resulting index. (Abesadze, 2013).

Analysis methods of the economic science were

Fig. 1.Unemployment Rate by Gender.(\%) employed, among them, statistical data processing, data grouping, inductive-deductive data analysis methods. The scientific study employs surveying, observation, as well as comparative, analytical, and graphical methods, which are used by the author to compare and analyse facts and assess solutions to specific issues. (Abesadze,2014).

\section{RESULTS}

Studying gender issues of employment and correcting the policy aiming at guaranteeing the employment gender equality on its basis is one of the priorities of the present government of Georgia. [Abesadze,2013.] The problem of unemployment is one of the acutest problems in Georgia and as the results of different statistical, conjunctive or social surveys evidence, often ranks first among the most important social-economic or political problems the country and Georgian people face. The problem of unemployment is one of the acutest problems in Georgia and as the results of different statistical, conjunctive or social surveys evidence, often ranks first among the most important social-economic or political problems the country and Georgian people face. (Abesadze, 2014).

Unfortunately, reality in our country is that abduction for marriage and premature marriages are still prevalent. In addition, women are often victims of violence from husbands or partners. Gender disbalances are significant in societal activities. We think that one clear example of stereotypical thinking is segregation upon selection of professions or

Average Monthly Earnings of Employees by Sex

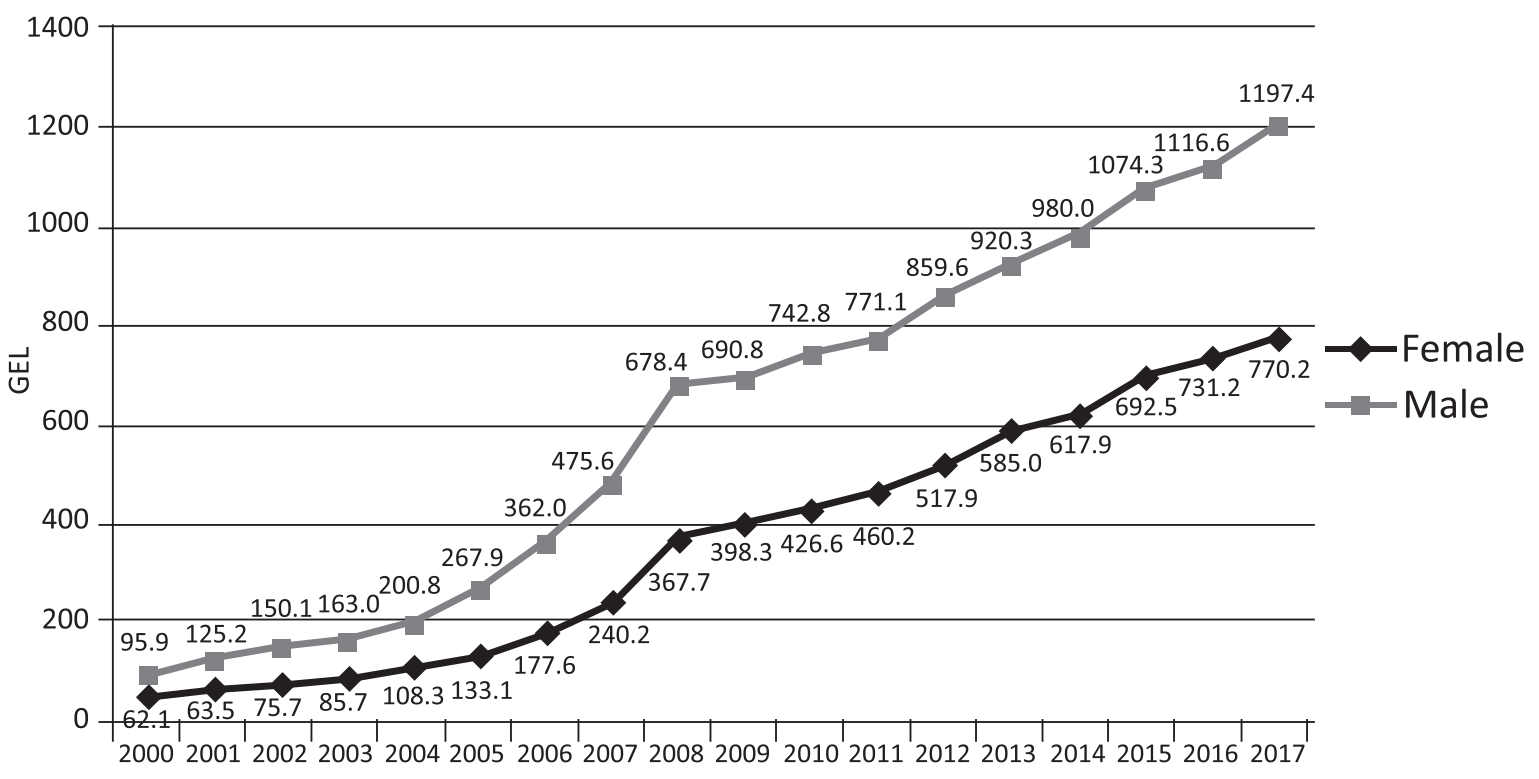

Source: Source: www. geostat.ge. Official web page of National Statistics Office of Georgia, last access 15/01/2018 
expectations of social positioning on the basis of sex. "So it is important analyze an environment, where men and women have different gender roles in political, social and societal life on the basis of sex differences». Some scientists, including Batler, [Batler, 2004] underline that sex is a complex mixture of individual activities and institutional influences, which is conditioned by power and influence of social code. It exists to form ideas about norms and deviation from norms. Sex categorizes individuals on the basis of «natural», «biological» and «bestowed by God». (Gorgadze,2015). The goal of Georgian law about gender equality is to "guarantee impermissibility of discrimination in every aspect of social life, create corresponding conditions for equal rights of men and women, as well as for realization of freedoms and opportunities; support avoidance and eradication of discrimination». However, we still meet gender disbalances in the field of employment.

It is fact that in Georgia number of employed men is more than women. A level of inactivity of women is almost two times higher than in men (correspondingly $42.0 \%$ and $21.8 \%)$. Unemployment rate of women has decreased by $1.4 \%$ in 2015 compared to 2016 and comprised $8.8 \%$. In the same period, unemployment rate of men has increased by $0.7 \%$ and comprised $14.2 \%$.

In 2017, unemployment rate for women Increased by 1.8 percentage points to 12.7 percent, and for men decreased by 1.6 percentage points and by 15 percent.

Indicators of level of inactivity also changed. The level of inactivity of women has increased by $1,8 \%$ and comprised
$58.0 \%$. The level of inactivity of men has decreased by $1,61 \%$ and comprised $78.2 \%$.

Changes for to the same period (2017/2016) are also indicators of activity level. The level of activity increased reased by 1.5 percentage points for women and decreased by 2.8 percentage points for men and 58.2 percent and 74.6 percent respectively.

We have interesting trend for indicators of employment on the basis of age. Number of employed men is especially high in the age group 45-54. Employment rate of men has been higher during the last 9 years, especially in the age group 15-24, where number of employed men is two timer higher than women.

Unemployment rate is especially high in youth. It is the main source of labor migration. Because of lack of corresponding experience, knowledge and skills, employers refuse to offer jobs to the youth and prefer more experienced personnel.

It is also fact that wage of employed men is higher than of women. Generally women earn less than men.

Growth rate of wages is also different. For example, in 2017 , average monthly wage of employed women was 770,2 Lari and of men - 1197,4 Lari (difference equals to 427,2 Lari). Wage of women is smaller in almost every field. For example, in agriculture the difference is 1.17 , in trade and repair of automobiles, consumer electronics and private usage items -1.63 , in hotels and restaurants -1.33 , in fishing -2.12 , in transport and communications - 1.45, in financial activities 2.17 , in education -1.2 , in state management -1.06 , in health protection and social assistance -1.55 etc. [11]Types of work

Fig. 2. Average monthly nominal earnings of employees by economic activity and sex, 2000-2017

Unemployment Rate by Gender, \%

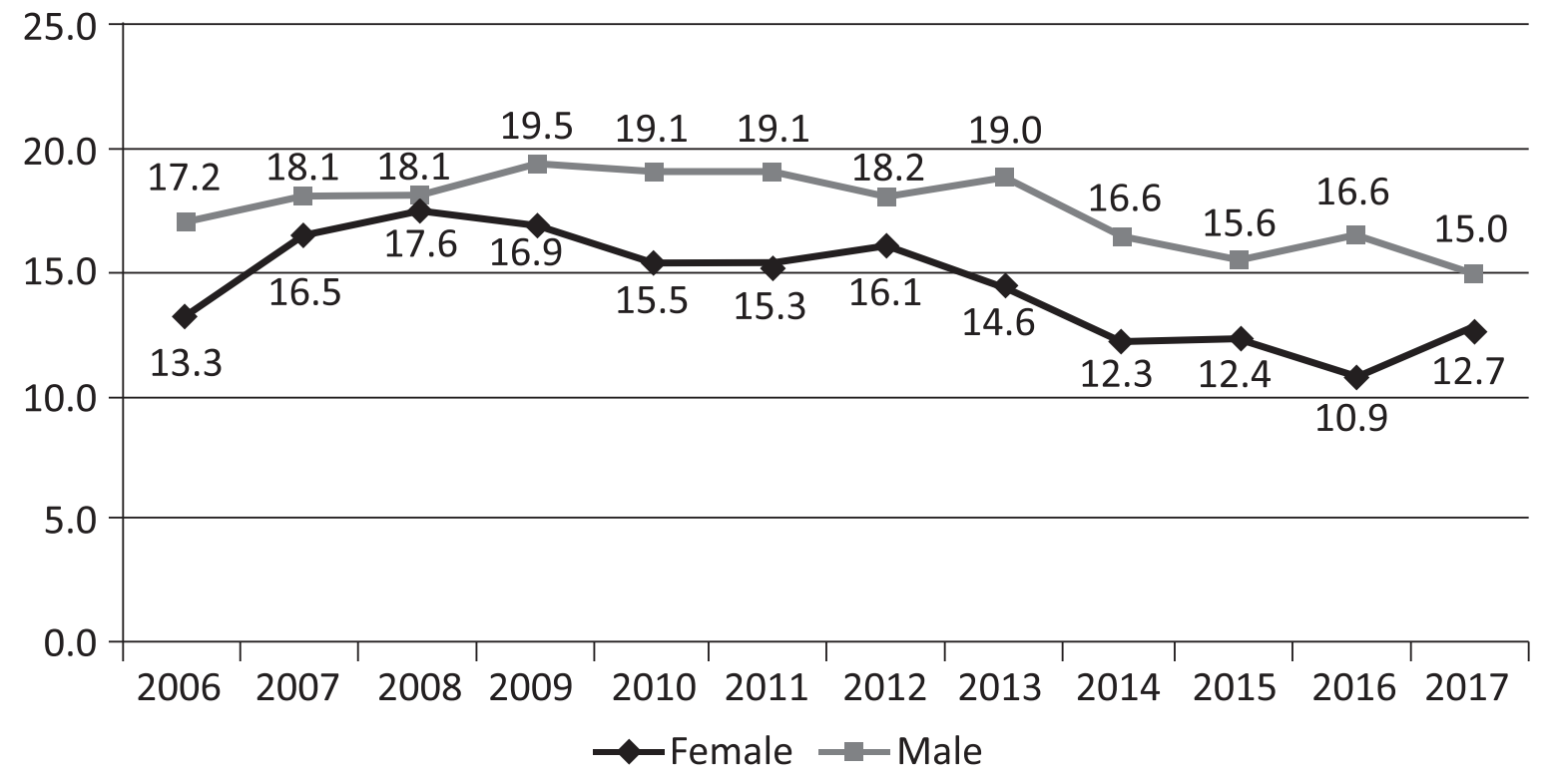

Source: www. geostat.ge. Official web page of National Statistics Office of Georgia, last access 15/01/2018 
performed by men and women are quite different, but both sex must have equal opportunity to reveal himself/herself and earn equal wage. It is also fact that in Georgia higher positions are usually occupied by men and there is a principle of socalled "glass ceiling", which implies creation invisible barriers preventing women from occupying high positions. 6h Article of 2nd chapter of Georgian law about gender equality regulates the principles of gender equality in labor relationships. It states that state supports equal availability of employment for both sexes. (Georgian law about gender equality, 2010).

What is an international practice in protection of labor relationships? For example, let us consider the experience of Iceland, as it has the best indicator in global gender index.

The law of Iceland obliges employer to take every measure to avoid segregation on the basis of sex at any job. In addition, the employer must care to distribute higher positions equally between men and women. If company has more than 25 employees, it is obliged to develop a program of gender equality and use principles of gender mainstreaming for a whole personnel. Companies must present a plan of gender equality or policy of personnel to the center of gender equality in defined terms. In other case they will pay fine, until they develop the program of gender employment (amount of fine is 50,000 Iceland Krona daily). Employer is also obliged to pay equal wage for equal work without distinction of sex. The law of Iceland states that employer must take any measure to support men and women combine their professional and family obligations. Besides, when employer establishes working hours, it is necessary to take into account employees' family conditions, as well as, demands of labor market. Employer must also help employee to return at work after maternity leave (both parents are indicated). The law of Iceland forbids publication of vacancy announcement, which prefers particular sex. Employers are forbidden to publish such announcement, which discriminates on the basis of sex. (Arjevanidze, 2012).

\section{CONCLUSIONS}

To optimize opportunities of working force on the basis of gender, it is necessary to correctly understand women's role and encourage their activities. These measures will support development of optimal employment policy.

Thus, the study has evidenced the necessity for the better availability of the information about

gender statistics for different types and sectors of business, outlined the existing gaps, priorities and major trends in gender employment, as well as specific measures to improve statistical methodology needed for statistical evaluation of employment dynamics. The gained result corresponds to the paper objective allowing concluding that designing employment gender indexes and regularly identifying the existing employment proportions based on it, predicting expected misbalance in employment, outlining the employment trends "dangerous" for the society and ultimately crushing the gender stereotypes may become the basis for the progress of the efficient employment policy.

\section{REFERENCES:}

1. Abesadze N. (2014). Statistics of unemployment in Georgia. Journal: Economy and management: Theory and practice. PP.15-20

2. Abesadze N. (2013). The methodological issues of the improvement of gender statistics of employment

- Economics and Management. PP.154-158.

3. Arjevanidze N. (2012). Gender equality - Review of Georgian and international legislation. Tbilisi. PP. 10-11. http://css.ge/files/ Papers/Nargiza_Arjevanidze,_Gender_Equality-legislation,_August_2012_Geo.pdf

4. Batler, J. (2004). Undoing Gender. New York and London. P. 22

5. Gelashvili S., Charekishvili L. (2016). The problems of gender statistics. Tbilisi, 2016. Gender discrimination at working place. Tbilisi.

6. Gender discrimination in labor relationships (2014). Tbilisi. P.51. http://article42.ge/wp-content/uploads/2016/03/.pdf

7. Gorgadze, N. Gender education at the initial stage of general educational schools (2015). Tbilisi. P. 22

8. Gochiashvili N. Analysis of working plans for support of women's employment (2014). Tbilisi.

National masterplan for gender equality in 2014-2016. Tbilisi.

9. Georgian law about gender equality (2010). 2nd chapter - guarantees for securing gender equality, 6 th article. Tbilisi.

10. Inter-parliamentary cooperation, women in national parliament (2013).1 February. http://www.ipu.org/wmn-e/classif.htm

11. Kvelashvili N., Abramia N., Liparteliani L., Tartarashvili T., Shioshvili G. (2013). The problems of youth employment in Georgia. Tbilisi.

12. Man and woman in Georgia. (2017). Geostat. Tbilisi.

13. The trends of employment and unemployment in Georgia, EPRC, Tbilisi, 2011.

14. Women's economic opportunities and challenges. Association of young economists. Tbilisi, 2014.

15. http://reports.weforum.org/global-gender-gap-report-2016/results-and-analysis/

16. \#199 decree of Georgian government about state strategy of formation of Georgian labor market (2013). Tbilisi. 


\section{SOCIO-ECONOMIC-GENDER DISBALANCES IN GEORGIA}

\section{NINO ABESADZE}

\section{Associate Professor}

Ivane Javakhishvili Tbilisi State University, Georgia

nino.abesadze@tsu.ge

\section{NATALIA ROBITASHVILI}

\section{Assistant Professor}

Batumi Shota Rustaveli State University, Georgia

robnato@mail.ru

\section{OTAR ABESADZE}

\section{Assistant Professor}

Caucasus University, Georgia

o.abesadze@gmail.com

\section{KEYWORDS: EMPLOYMENT, GENDER, STEREOTYPE, INDEXES, RATE}

For citation: Abesadze N., Robitashvili N., Abesadze O. (2019), Socio-Economic-Gender Disbalances In Georgia, Globalization And Business, №7, pp. 143-147. https://doi.org/10.35945/gb.2019.07.017

\section{SUMMARY}

Introduction and aim According to the policy towards gender equality, Georgia has become one of the most reformed countries in the Caucasus. Despite the fact that many steps have been taken in this regard, the problems are still in the society. The main objective of the study is to identify and analyze gender imbalances in the country on the background of gender stereotypes in the context of civil cognitive levels.

Research methodology: In development of the article, generally accepted qualitative and quantitative data analysis methods of the economic science were employed, among them, statistical data processing, data grouping, inductivedeductive data analysis methods. The scientific study employs surveying, observation, as well as comparative, analytical, and graphical methods, which are used by the author to compare and analyze facts and assess solutions to specific issues.

Results and implications: The paper considers the gender aspects of Discussion of inequality problems in Georgia. Besides, the trends of unemployment and their reasons are identified and the international instruments of protection of human rights regulating the equality between the men and the women in Georgia are considered. In addition, based on the statistical data, is given the analysis of employment and unemployment in a gender respect; a particular accent is made on the need of International practice of gender protection.

Conclusion: Stereotypical views on gender roles still exist in Georgia: the function of women is the care and upbringing of children, doing homework, and man-taking care of family finances.

The fact is that more men employed in Georgia than women. The level of inactivity in women is almost twice as high as in men with a similar indicator of $42.0 \%$ and $21.8 \%$ respectively. In 2017, unemployment rate for women Increased by 1.8 percentage points to 12.7 percent, and for men decreased by 1.6 percentage points and by 15 percent. Changes for to the same period are also indicators of activity level. The level of activity increased reased by 1.5 percentage points for women and decreased by 2.8 percentage points for men and 58.2 percent and 74.6 percent respectively.

Interesting trends are shown by employment indicators according to age marks. The number of men employed by the 45-54 age group is significantly higher than the number of women employed for the whole nine years, indicating the employment rate of women, especially in the 15-24 age group where the number of men employed is twice as high as the number of women employed.

It is also true that the average level of compensation for women is lower than men. Their rates of growth are also different. 